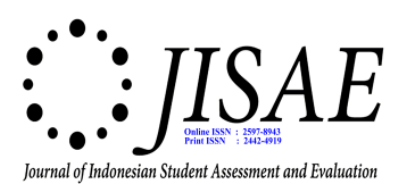

\title{
DEVELOPMENT OF BIOLOGY TEST OF CREATIVE THINKING-TORRANCE TEST (BTCT-TT) ASSESSMENT TO IMPROVE STUDENTS' CREATIVE THINKING SKILLS
}

\author{
Radiah \\ radiah.sma8@gmail.com \\ Senior High School 8 Malinau \\ Cipta Utama St., Kuala Lapang. Malinau District
}

\begin{abstract}
This research aims to developing the Biology Test of Creative Thunking-Torrance Test (BTCT-TT) assessment in studying Biology for high school student in grade 11. This type of research is Research\& Development (R \& D) with 4D (Define, Design, Develop, and Disseminate). This study have develodped 37 items that are valid and reliabel. BTCT-TT was tested on 150 high school students, the results showed the average score of students' creative thinking skills was significantly releted to students who received BTCT-TT assessment and Conventional assessment.
\end{abstract}

Keywords: Biology Test of Creative Thinking-Torrance Test (BTCT-TT), Creative Thinking

\section{INTRODUCTION}

Education in the 21 st century should be supported by an education system that is oriented to student creativity. As a developing country, Indonesia needs creative human resources who are able to make a meaningful contribution to science, technology, arts, and national health.Therefore education should be focused on developing the creativity of students. therefore education should focus on students' creativity so that one day they can meet their personal needs, community needs and the needs of the Indonesian nation.

Data from the results of the Program for International Student Assessment (PISA) research examining the ability of junior and senior high school students in mathematics, science and reading shows that Indonesian students' ability to answer PISA questions is low. The 2011 Trends in International Mathematics and Science Studies (TIMSS) results, the average grade of VIII science is only 406 and is in 40 th position out of 42 countries. The percentage of Indonesian students who can answer the low level questions is $54 \%$, the middle level is $19 \%$, the high level is $3 \%$ and none of the students can answer the advanced level. This results is very alarming because the mastery of mathematics and science must be owned by every individual who lives in the 21 st century, where science and technology continue to develop that requires young people to think innovative and creative in solving science problems.

The assessment model that are often used by teachers in Indonesia is conventional assessment model. The conventional assessment model only measure students low-level abilities. The students are not directed to develop high-level abilities so that students are only able to memorize concepts but are difficult to apply it in every day life.

Assessment of the Biology Test of Creative Thinking-Torrance Test (BTCTTT) is an assessment that adapts the TTCT assessment, the indicators on the TTCT assessment are integrated with Biology learning indicators. TTCT is the most widely used creativity assessment in the world. TTCT has two forms of test namely 
verbal and figural forms. This form of test was developed in Indonesia by Utami Munandar in 1977. In addition to assessing students 'creative abilities, TTCT can also improve students' creative abilities in learning and everyday life. TTCT assessment is a comprehensive assessment model and can measure all aspects of creativity so that this type of assessment is very appropriate to measure and enhance student creativity

\section{Creative Thinking}

Creativity is the interaction between intelligence, process, and the environment in which an individual or group produces products that are clear and new and useful as defined in society. (James K. Kaufman, et al, 2013: 2). Torrance (1966), developed a measure of creativity with indicators of fluency, flexibility, originality and elaboration. Whereas Guilford (1967) measures divergent thinking by using a test format that is generally subject to respond to many stimuli, each using a special component of the structure of the intellect. (Utami Munandar, 2012: 64)

One of the critical problems in researching, identifying, and developing creativity is that there are so many definitions of creativity, but no definition is universally accepted. Keeping in mind the complexity of the concept of creativity, this is neither possible nor necessary, because creativity can be viewed from various aspects. Although interrelated, but the emphasis is different. (Isaken, 1987: 299 ) in analyzing more than 40 definitions of creativity, concluded that creativity is generally formulated in terms of personal (person), process and product. Creativity can also be viewed from the personal and environmental conditions that encourage (press) individuals to creative behavior. Rhodes called these four types of definitions of creativity as "Four P's of Creativity: Person, Process, Press, Product". Most definitions of creativity focus on one of these four P's or their combinations. These four $\mathrm{P}$ are interrelated: The creative person engages in the creative process, and with the support and encouragement of the environment, produces creative products.

\section{Torrance Testof Creative Thinking (TTCT)}

Torrance Test Creative Thinking (TTCT) was developed by Dr. E. Paul Torrance in 1966. Kyung Heem Kim explained that TTCT is the most widely used creativity test in measuring creativity in education in the world. (Kyung Hee Kim, 2006: 1). This is similar to what was stated by Solange Wechsler: "... Torrance neither concludes that his tests assess all dimensions of creativity ..". (Solange Wechsler, 2006: 16).

TTCT is a test tool that can be used to measure all forms of creativity. As stated by Torrance that TTCT is a creativity test tool that can measure all forms of creativity. Torrance $(1966,1974)$ suggested the use of TTCT (1) to understand the human mind and its functions and development (2) to find an effective basis for individualization instruction (3) to provide instructions for remedial programs and psychotherapy (4) to evaluate the effects of programs education, materials, curriculum, and teaching procedures (5) To find out latent potential. (Kyung Hee Kim, 2006: 7)

Thus it can be said that the Torrance Test of Creative Thinking (TTCT) is a creativity test tool that can be used in general for example in classroom learning 
activities, assessment of learning outcomes, measuring student creativity while increasing student creativity.

Although TTCT is generally used for assessment in identifying gifted children. However TTCT can be used in research and experiments, for general use, for instructional planning, and for determining students' abilities. In this study TTCT will be used to evaluate the learning process. TTCT can trigger stimulant expressions (simultaneous) of several creative mental speeches in measuring fluency, flexibility, originality, and detail (elaboration).

TTCT consists of verbal and figural forms, both of which relate to the creative process and include different types of thinking. This test is specifically designed to make student activities interesting and challenging, from pre-school education to high school graduation. TTCT can be used individually or in groups. Verbal form consists of seven sub-tests: (1) asking unusual, (2) guessing causes, (3) guessing consequence, (4) product improvement, (5) unusual uses, (6) unusual questions, (7) just suppose. The figural form consists of three sub-tests: (1) picture construction , (2) picture completion and (3) paralel lines. (Utami Munandar, 2012: 58-66). The activities as well as their descriptions for inclution in the TTCT are summerized in Tables 1 and 2.

Table 1

Test Activities in Torrance Test Creative Thinking Verbal Form A

\begin{tabular}{lll}
\hline Activity & Description \\
\hline 1. Asking & $\begin{array}{l}\text { Ask questions to know for sure what is happening in the } \\
\text { drawing } \\
\text { Give possible causes that lead to the action shown in the } \\
\text { drawing }\end{array}$ \\
2. Guessing Causes & $\begin{array}{l}\text { List possible consequences resulting from the action in } \\
\text { the drawing }\end{array}$ \\
3. Guessing & $\begin{array}{l}\text { List the cleverest, most interesting and unusual ways of } \\
\text { changing a stuff toy elephant to make it more fun to play }\end{array}$ \\
4. Product & $\begin{array}{l}\text { Improvement } \\
\text { Think about possible uses for cardboard boxes. }\end{array}$ \\
5. Unusual Uses & Propose for questions about cardboard boxes. \\
6. Unusual questions & List things that would happen in an improbable \\
7. Just Suppose &
\end{tabular}

Verbal tests are scored for smoothness, flexibility and originality, while figural tests are added to the scores for elaboration. TTCT implementation is given a time limit in doing the test because to a certain degree TTCT requires a press (booster, pressure) so that students' creative mental functions are triggered, this can direct and stimulate students to think creatively. (Utami Munandar, 2012: 58-66).

Tabel 2

The Activities in Torrance Test of Creative Thinking Figural Form A 


\begin{tabular}{|c|c|}
\hline Activity & Description \\
\hline $\begin{array}{l}\text { 1. Picture } \\
\text { construction }\end{array}$ & $\begin{array}{l}\text { Draw a picture with a given tear drop shape an an } \\
\text { integral part, and give a title for the drawing }\end{array}$ \\
\hline $\begin{array}{l}\text { 2. Picture } \\
\text { Completion }\end{array}$ & $\begin{array}{l}\text { Add lines to incomplete figures and give tiles for the } \\
\text { drawings }\end{array}$ \\
\hline 3. Parallel lines & $\begin{array}{l}\text { Make picture from pairs of straight lines and entitle the } \\
\text { drawings }\end{array}$ \\
\hline
\end{tabular}

Abdul kamil marisi (2007) in his research concluded that by developing a test from TTCT in measuring students' creative thinking abilities, TTCT can improve students' fluency in making questions, quessing the cause and effect of events, developing in the benefits of on object, and using things in extraordinary ways. This is supported by the research of Grace et al(1996), their research successfully developed an assessment of creativity by developing an TTCT creativity assessment. The measuring instrument that was successfully developed was Design Thinking Creative Thinking (DTCT). DTCT is an innovation of standardized creativity that measures directly problem-based skills. The results of this study explain that TTCT can be develoved in measuring students' creative thinking abilities in learning science.

Kyung Hee Kim from Eastern Michigan University concluded that TTCT is a good measure of creativity and is not only used to identify the creativity of gifted children, but also to find and encourage the creativity of everyday life. This is supported by Solange Wechsler (2016), his research concluded that there is a significant relationship between creative achivement with creativity indikators in TTCT. Thus it can be concluded that TTCT can measure creativity in general and can be developed into a measure of creativity in learning Biology in the classroom.

\section{METHOD}

This research is a type of research development or Research and Development (R\&D). Research and development are research methods used to produce certain products, and test the effectiveness of these products. (Sugiyono, 2014: 407). This development research model uses the 4D model, this research model is a research model of Sivasailam Thiagarajan, et al. Sivasailam Thiagarajan, et al (in Sugiono 2016: 37) suggested that this research model consisted of 4 stages namely: Define, Design, Develop, and Disseminate abbreviated with 4D.

This research was conducted at SMAN 8 Malinau, Malinau Regency, North Kalimantan Province in February to September 2018.

The population in this study were all high school students in Malinau were students of class XI SMAN 1, SMAN 3, SMAN 4, SMAN 5, SMAN 8 Malinau. The development of the BTCT-TT instrument was carried out by testing the validity and reliability, validity and reliability testing of 5 experts, 20 panelists, and 30 students. Trial questions for 280 high school students, and BTCT-TT effectiveness testing was carried out on 50 students from SMAN 8 Malinau, 25 students as the experimental group and as many as 25 students as the control group. 
Data analysis Techniques used Qualitative Analysis Techniques and Quantitative Analysis Techniques. Qualitative analysis techniques with interactive analysis consisting of three components, namely, data reduction, data exposure and conclusion drawing. Quantitative analysis techniques are carried out so that the conclusions obtained from testing research hypotheses can be scientifically justified, statistical analysis techniques that must meet the requirements are: 1) normality of data, and 2) homogeneity of variance. After the data from the population are normally distributed and come from the same or homogeneous variants, they are then statistically tested with correlated t-tests.

\section{RESULTS AND DISCUSSIONS}

\section{Development Biology Test of Creative Thinking Torrance Test (BTCT-TT)}

BTCT-TT is made by matching the indicators on the TTCT with the indicators on Biology subject matter. the first stage in developing the BTCT TT is to synthesize the TTCT theory to a psychology lecturer from Jakarta State University.

BTCT-TT instruments used in. This research has a breakdown of 100 questions. The attributes of 100 items developed are presented in Table 3.

Table 3 material distribution on BTCT-TT

\begin{tabular}{lllccc}
\hline \multirow{2}{*}{ No } & \multirow{2}{*}{ Indikator on BTCT-TT } & \multicolumn{3}{c}{ Number of items on the topic } \\
\cline { 3 - 5 } & & & cell & $\begin{array}{c}\text { Plant } \\
\text { Tissue }\end{array}$ & $\begin{array}{c}\text { Animal } \\
\text { Tissue }\end{array}$ \\
\hline 1 & Asking unusual & 7 & 2 & 3 \\
2 & Guessing Causes & 13 & 3 & 4 \\
3 & Guessing Consequence & 15 & 5 & 2 \\
4 & Product Improvement & 1 & 2 & 4 \\
5 & Unusual Uses & 0 & 7 & 5 \\
6 & Unusual Questions & 5 & 2 & 4 \\
7 & Just Suppose & 9 & 4 & 3 \\
\hline & Total & 50 & 25 & 25 \\
\hline
\end{tabular}

Validity and Realibity Test

The validity and reliability test is conducted to find out the extent to which the BTCT instrument precisely measures what it wants to measure according to the concepts and indicators based on the theory set, then the instrument is firstly tested by one Psychology lecturer, one education evaluation lecturer and two Biology lecturers. The experts' recommendations aim to find out the accuracy or relevance of the instrument's points with the measurement objectives. as explained in the concept definition, operational definition, and grid.

The second stage, involved 20 panelists consisting of Biology teachers who assessed the appropriateness of the statement items with the existing indicators on the BTCT-TT instrument grid. The results of the assessment were analyzed to 
determine the index of content validity with the Aiken Validity Index and construct validity with convergent references.

The results of the validity test of experts and panelists, the validity of the instrument point 1 to item 100 is greater than the validity of criteria 2.5 so that the item is declared valid but there is still a need to be revised.

Trial and revision

Test the validity and reliability of the instrument is done by testing the instrument that has been declared valid by the expert 3 times. Trial 1 was conducted on 50 students of SMAN 8 Malinau. The validity of the BTCT-TT instrument was calculated using the product moment correlation formula, KR20 while the instrument reliability used Cronbach's alpha reliability. The results of the analysis in Experiment 1 showed that out of 100 questions developed there were 63 valid and reliable items.

Table. 4. The valid items on first trial

\begin{tabular}{lllll}
\hline \multirow{2}{*}{ No } & \multicolumn{1}{c}{ Indikator on BTCT-TT } & \multicolumn{3}{c}{ Number of items on the topic } \\
\cline { 3 - 5 } & & Cell & Plant Tissu & $\begin{array}{c}\text { Animal } \\
\text { Tissu }\end{array}$ \\
\hline 1 & Asking unusual & 6 & 2 & 2 \\
2 & Guessing Causes & 9 & 2 & 3 \\
3 & Guessing Consequence & 8 & 1 & 2 \\
4 & Product Improvement & 0 & 0 & 2 \\
5 & Unusual Uses & 0 & 3 & 3 \\
6 & Unusual Questions & 5 & 2 & 3 \\
7 & Just Suppose & 5 & 2 & 2 \\
\hline & Total & 33 & 12 & 17 \\
\hline
\end{tabular}

valid and reliable instruments in trial 1 were then tested on 80 high school students, 40 students from SMAN 8 Malinau, and 40 students from SMAN 3 Malinau. The results of trial 2 are shown in table 5.

Table. 5. The valid items on second trial

\begin{tabular}{lllcc}
\hline \multirow{2}{*}{ No } & \multicolumn{1}{c}{ Indikator on BTCT-TT } & \multicolumn{3}{c}{ Number of items on the topic } \\
\cline { 3 - 5 } & & cell & $\begin{array}{c}\text { Plant } \\
\text { Tissue }\end{array}$ & $\begin{array}{c}\text { Animal } \\
\text { Tissue }\end{array}$ \\
\hline 1 & Asking unusual & 5 & 2 & 2 \\
2 & Guessing Causes & 6 & 0 & 0 \\
3 & Guessing Consequence & 5 & 0 & 0 \\
4 & Product Improvement & 0 & 0 & 1 \\
5 & Unusual Uses & 0 & 1 & 3 \\
6 & Unusual Questions & 4 & 2 & 3 \\
7 & Just Suppose & 3 & 0 & 1 \\
\hline & Total & 23 & 5 & 10 \\
\hline
\end{tabular}

The second trial produced 38 items that were valid and reliable. The results of the second trial were then trialled again to 150 high school students, as 
many as 40 students from SMAN 1 Malinau, 40 students from SMA 3 Malinau, 40 students from SMAN 8 Malinau, 15 students from SMAN 4 Malinau, and 15 students from SMAN 5 Malinau. The analysis shows that there are 37 valid and reliable items. The results of the third trial validity test are listed in table 6 .

Table. 5 The valid items on third trial

\begin{tabular}{lllll}
\hline \multirow{2}{*}{ No } & \multirow{2}{*}{ Indikator on BTCT-TT } & \multicolumn{3}{c}{ Number of items on the topic } \\
\cline { 3 - 5 } & & cell & $\begin{array}{c}\text { Plant } \\
\text { Tissue }\end{array}$ & $\begin{array}{c}\text { Animal } \\
\text { Tissue }\end{array}$ \\
\hline 1 & Asking unusual & 4 & 2 & 2 \\
2 & Guessing Causes & 6 & 0 & 0 \\
3 & Guessing Consequence & 5 & 0 & 0 \\
4 & Product Improvement & 0 & 0 & 1 \\
5 & Unusual Uses & 0 & 1 & 3 \\
6 & Unusual Questions & 4 & 2 & 3 \\
7 & Just Suppose & 3 & 0 & 1 \\
\hline & JUMLAH & 22 & 5 & 10 \\
\hline
\end{tabular}

the results of the distribution of BTCT-TT indicators on first trial, second trial, and third trial can be seen in graph 1 . Graph 1 shows that there is a decrease in the number of questions for each BTCT-TT indicator especially on product development indicators

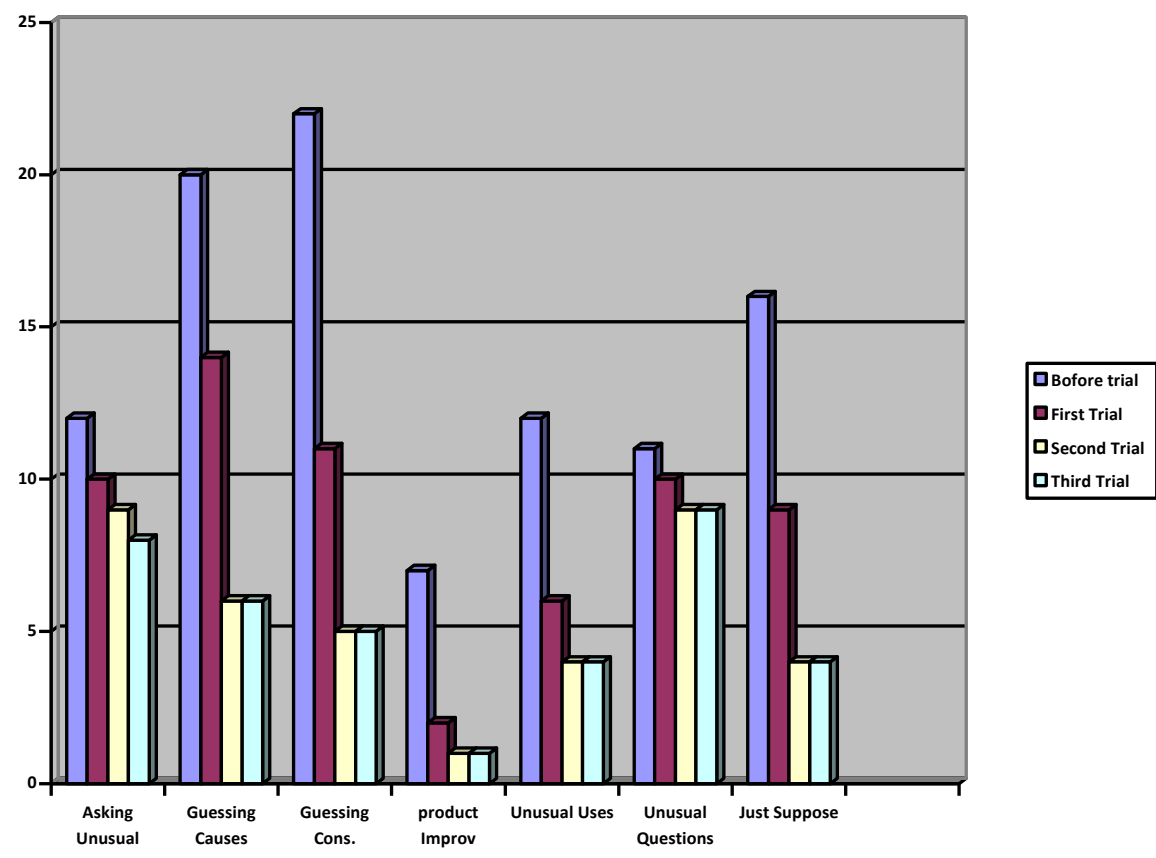

Grafik 1. Distribution of BTCT-TT indicators on first trial, second trial, and third trial 


\section{Effect of BTCT-TT on student creativity}

Items that were successfully developed (valid and reliable) as many as 36 items are tested for their influence in increasing student creativity. This study uses a factorial experimental design with one independent variable being manipulated

Creative thinking instruments used to measure the effect of BTCT-TT in enhancing student creativity are creative measuring instruments made by researchers that have been tested for validity, reliability, normality, and homogeneity tests. Testing the creativity instrument developed by 10 items. The development of creativity instruments involved 3 biology lecturers from biology universities, 20 biology teachers, 30 high school students, out of the 10 items developed there were 6 valid and reliable items

The method and design or experimental design used were pretest-posttest control group design, 25 students as the experimental group and 25 students as the control group. Provision of treatment to the experimental group for 3 months by giving BTCT-TT assessment while the control group with conventional model assessment. The difference in mean scores is known from the Mann Whitney test. To see the significance level of the difference between the two treatment groups, the Mann Whitney test was performed. The results of the Mann Whitney test on the two treatment groups are shown in table 6 .

Table 6 Difference in average scores of students' creative thinking abilities.

\begin{tabular}{llccc}
\hline \multicolumn{1}{c}{ Student } & Treatment & Pretest & Post Test & Signifikansi \\
\cline { 1 - 3 } Asessment & Konvensional & 53.46 & 45,880 & \multirow{2}{*}{0,000} \\
\cline { 2 - 3 } Model & BTCT-TT & 54.21 & 68,560 & \\
\hline
\end{tabular}

From the results of the descriptive analysis above, it shows that the creative thinking ability of students who get BTCT-TT assessment is higher than students who get Conventional assessment. From the results of the descriptive analysis above shows that there is a significant difference in the average ( $p$-value $=0,000$ $<0.05$ ) of the creative thinking abilities of students who are given an assessment of the Biology Test of Creative Thinking-Torrance Test (BTCT-TT) and those given Conventional assessment,

From this result also shows that there is an average difference between the initial abilities of students and after giving BTCT-TT assessments. The difference in students' creative thinking abilities between the control group and the experimental group was seen after students were given a BTCT-TT assessment. The initial ability of students between the control group and the experimental group was 0.2117 whereas after giving BTCT-TT assessments the difference in students' creative thinking abilities became 22,680. This shows that BTCT-TT can improve students' creative thinking abilities.

The analysis shows that there are differences in the level of creative thinking ability of the experimental class with the control class. This means that the Biology Test of Creative Thinking -Torrance test (BTCT-TT) assessment influences students' creative thinking abilities. The effect of assessment because the TTCT 
assessment model is very appropriate to be used in improving creative thinking skills. This is in line with research conducted by Abdul Kamil Marisi's research results in his research concluding that by developing tests from the Torrance Test of Creative Thinking (TTCT) in measuring students 'creative thinking abilities can increase students' fluency in making questions, guessing the causal effects of events, develop the benefits of an object, and use things in extraordinary ways. Other supporting research, namely research Kyung Hee Kim from Eastern Michigan University concluded that the Torrance Test of Creative Thinking (TTCT) is a good measure of creativity and is not only used to identify the creativity of gifted children but also to discover and encourage the creativity of everyday life. The reliability of TTCT is also evidenced by Solange Wechsler who concluded that there is a significant relationship between creative achievement with creative indicators in TTCT. This is shown in testing the validity and standardization of TTCT in Brazil, creative indicators in the form of verbal and figural tests show that TTCT is universal, not only can be used in developed countries like America but TTCT can measure the ability of creativity in developing countries like Brazil.

Torrance Test of Creative Thinking (TTCT) is a measuring tool that can measure all forms of creativity. (Solange Wechsler, 2006: 16). This shows that TTCT can be widely used, both in the fields of psychology, research, and education. At present, the use of TTCT in the field of education is more widely used by BK teachers to determine student talent. Teachers are expected to develop TTCT in the form of items to measure student learning outcomes.

TTCT is a test tool related to the creative process, this test is structured in such a way as to make its activities interesting and challenging for students. (Utami Munandar, 2012: 65), Torrance is the longest test that will be continuously published from different thoughts, the most widely studied, and the most widely used in the influence of education (Jmaes C. Kaufman, 2012-25). Thus TTCT is a test tool that can enhance student creativity and this test tool can be developed into a different test tool but still related to creativity. In this study the authors developed TTCT into BTCT-TT by integrating TTCT indicators into existing indicators in Biology lessons to improve students' creative thinking abilities. This is in line with the research of Grace Hawthorne et al who succeeded in developing a creativity measurement tool by developing a creativity measurement tool from TTCT. The measuring instrument that was successfully developed was the Design Thinking Creativity Test (DTCT.) The measuring tool developed in Hawthome's research is based on the principles of design thinking and can function as an assessment that reflects the problem-solving needs of the twenty-first century. Specifically, DTCT is an innovation of standardized measurement tools that directly measures problem-based skills. The results of this study explain that the measurement of TTCT creativity can be broadly developed.

Currently teachers in Indonesia have developed many innovative and creative learning models and media to welcome the 21 st century, but few teachers have developed assessment models. This causes the learning model and media do not used function optimally because the measuring instruments used are not appropriate. According to W.S. Winkel S.J (2012), evaluation methods and tools must be used in accordance with the kinds of achievements to be achieved. The Biology Test of Creative Thinking-Torrance Test (BTCT-TT) is an evaluation tool 
that can be a measuring tool that functions to measure students' creative thinking abilities in learning Biology. Besides being able to measure students' creative thinking abilities, this BTCT-TT can also increase student motivation in working on problems, as much as $85 \%$ of students prefer BTCT-TT as an evaluation tool compared to the questions that are generally used by the teacher. They argued that the questions teachers often used during tests made them tense and quickly forgot the material they had memorized before

\section{CONCLUSION}

The initial conditions of students before getting an assessment of Biology Test of Creative Thinking is to have the same ability and low crafting thinking. Development of Biology Test of Creative Thinking-Torrance Test (TTCT-TT) using the 4D model from Sirvasailam Thiagarajan et al. Produced 38 items and Groups of students who get BTCT-TT assessments have higher creative thinking abilities than groups of students who get conventional assessments.

\section{REFERENCES}

AS Munandar, dalam C Semiawan, AS Munandar \& S. C. U. Memupuk Bakat dan siswa Sekolah Menengah. Jakarta: Rieneka Cipta, 1987.

Arikunto.,Suharsimi . Dasar-dasar Evaluasi Pendidikan. Jakarta: Bumi Aksara, 2013.

Ambarjaya, S Beni. Teknik-teknik Penilaian Kelas. Bogor: CV Regina, 2009.

Alberta Teachers Associaton, Example Torrance Test of Creative Thinking. 2014

Djaali, Pudji Mulyono, dan Ramly. Pengukuran dalam Bidang Pendidikan. Jakarta: Pascasarjana UNJ, 2000.

Naga, Dali Santun. Teori Sekor pada Pengukuran Mental. Jakarta: PT Nagarani Citrayasa, 2013.

Isaken, S. G., \& Dorval, K. B. Toward an improved understanding of creativity within people: The level- style distinction. In S. G. Isaksen, M. C. Murdock, R. L. Firestien, \& D. J. Treffi nger (Eds.), Understanding and recognizing creativity: The emergence of a discipline (pp.299-330). Norwood, NJ: Ablex. (1993)

Kaufman C James, dkk. Essentials of Creativity. Amerika Serikat : Wiley. 2013.

Kerlinger, Fred N. Asas-asas Penelitian Behavioral. Yogyakarta : Gadjah Mada University Press, 2006.

Kim, Kyung Hee. Can We Trust Creativity Tests? A Review of the Torrance Tests of Creative Thinking (TTCT). New York : Creativity Research Journal vol $18,2006$.

Munandar, Utami. Pengembangan Kreativitas Anak Berbakat. Jakarta: Rineka Cipta, 2002. 
Marisi, Abdul Kamil . Efektivitas Model Pengukuran Kreativitas dalam Pembelajaran Hemisphere kanan (HK) untuk Meningkatkan Kreativitas Siswa Kelas V dalam Mata Pelajaran IPA di Sekolah Dasar .Yogyakarta: Jurnal PEP UNY No 2, 2007.

Semiawan, Conny. dkk. Memupuk Bakat dan Kreativitas Siswa Sekolah Menengah, Petunjuk bagi Guru dan Orang Tua. Jakarta: Gramedia, 1987.

Supranata, Sumarna . Panduan Penulisan Tes Tertulis. Bandung: PT Remaja Rosdakarya, 2004.

Sugiyono, Metode Penelitian Pendidikan, Bandung:Alfabeta, 2014.

Wechsler, Solange. Validity of the Torrance Tests of Creative Thinking to the Brazilian Culture. New York, Creativity Research Journal. 2006.

W.S. Winkel S.J, Psikologi Pengajaran. Yogyakarta : Sketsa, 2002.. 